沖縄県伊平屋村に打ける養殖モズク生産労働をささえる地域的条件

\author{
森 畺 一 郎* \\ キーワード：モズク盖殖，省力化，互助協働，含蜜糖，伊平屋村
}

\section{I 、はじめに}

\section{1. 研究の目的}

離島地域に和ける水産業は，流通に打解度 の維持や輸送コストの問題などから，一般的には 不利な条件の下にあるといえる。しかしながら吉 木（1979）は，離島地域が有する高い資源豊度と 優良な労働力の存在から，200海里時代に批ける 離島漁業発展の可能性に言及している。長谷川・ 常（2002）は, 利用度が低く, 水産養殖業のため の広大な漁場を確保できるという島嶼外縁部海域 のもつ有利性を指摘している。これらの研究は, 漁業, なかでる水産着殖業に関しては, 離島地域 が，不利性とともに一定の有利性をもつことを示 唆している。

水産盖殖業は，漁業集約化を促す性格を有して 扣り（大島，1964）、これにかかわる労働力につ いてみると，浦城（1993）が指摘しているょう に, 遊休性の排除といった水準にまで効率化され 投下される。さらに水産養殖業に拈いては, 養殖 される生産物の生物的特性から, その管理作業に 季節的な偏りがみられ，ある時期に怙いては集中 的な労働力投下が必要となる場合が多い。この場 合，農業や漁業など，地域に括ける既存の産業と の間で, 労働力の調整にかかわる問題が生じるこ ととなるが，労働力の確保が容易ではないと考兄 られる離島地域で展開される水産着殖業において は，この問題はいか澥決されているのであろら か。

* 三重県立稲生高等学校・三重大学大学院
大島（1966）は, 離島地域に和ける高年層や女 子の潜在労働力の存在を指摘し, 加えて漁期には 漁業にあてられる労働力が水産養殖業に転用され ている事例を報告している。また中村（2003） は，漁業の島に沏いて，まき網漁業による飼料の 確保を基盤とした水産養殖業が，地域をささえる 経済的な柱として確立されている事例林の 報告を行っている。ここでは, 収益性の高い水産 養殖業に漁家経営の重点が招かれ, 周年に打いて 優先的に労働力が投下されている。これらは，水 産養殖業が導入される以前から営まれてきた漁業 にかかわる労働力が, 水産養殖業にあてられた事 例である。

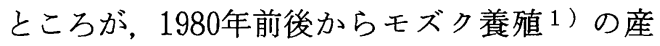
地形成がなされた沖縄県は, 歴史的に農業がさか んで，産業としての漁業の発達があまりみられな かった地域である（上田，1987）。この沖縄県に 点在する離島地域に抋いては, 水産養殖業にかか わる労働力の調達に関して, ぞのような問題が存 在し，それはどの上らに解決されているのだらら か。

沖縄県のモズク養殖に怙いては, 農業との兼業 経営の事例が多くみられる(森, 2003)。沖縄県 でさかんな農業のらち，とくにサトウキビ生産に 捛いては, 冬季の收檴期を中心集中的な労働力 の投下が必要となる（来間，1979）。動員可能な 労衝力に限りがあり，また臨時の雇用2）によっ て繁忙期をのりきるといらことが容易ではない離 島地域に拰いては, やはり冬季海繁忙となるモズ 

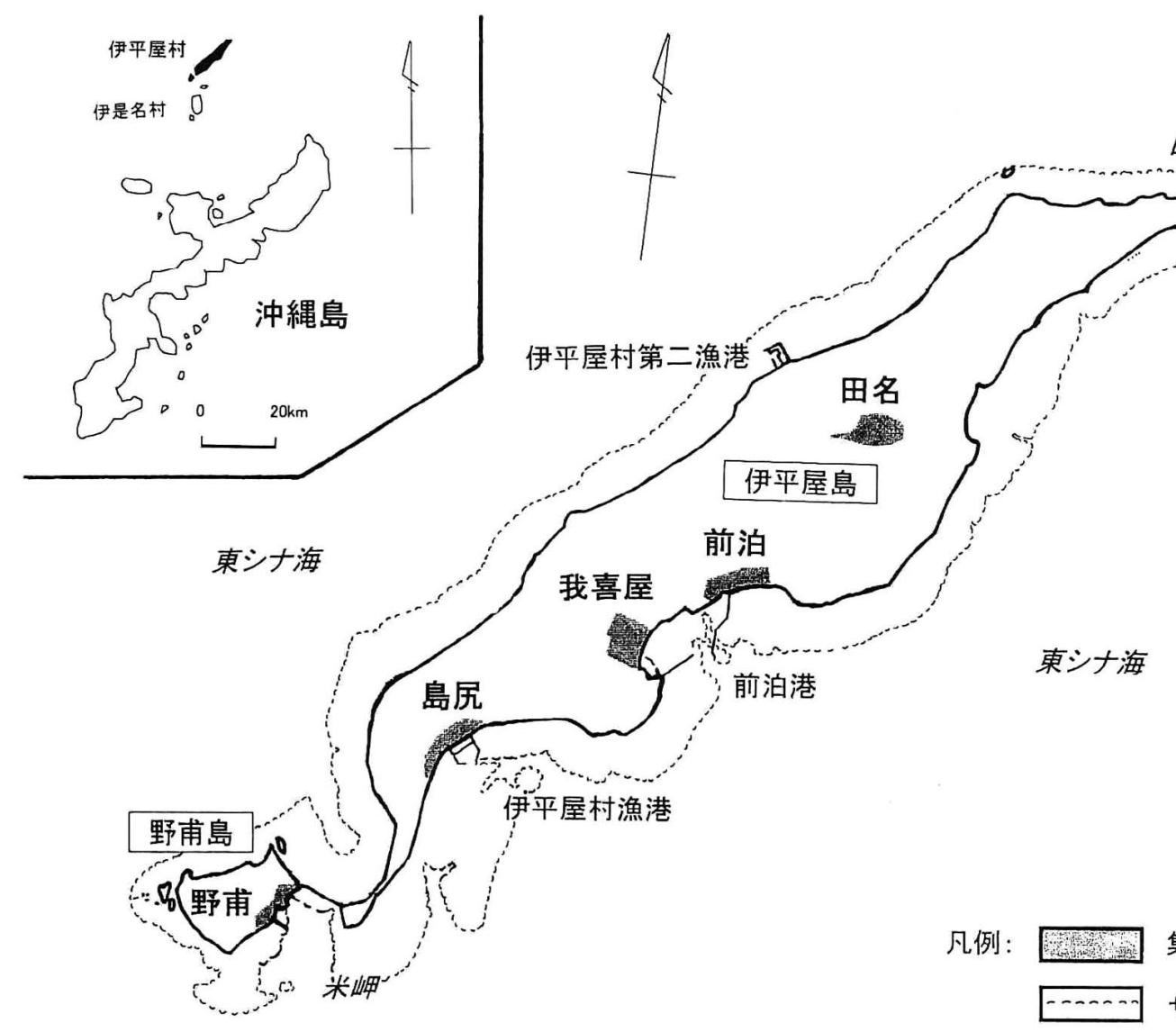

集落

サンゴ礁縁

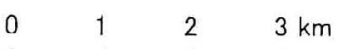

第 1 図 研究対象地域

昭和63年国土地理院発行 2.5 万分の 1 地形図上り作成

ク養殖とサトウキビ生産との兼業経営を行ららえ で困難が生じる。にもかかわらず，モズク養殖が 地域の農業とともに存立し、モズク養殖産地が形 成されてきた背景には，何らかの条件が存在する と考光られる。

本研究では, 沖䋥県離島地域のもつ政策的背景 および社会構造が，地域の生産労働をどのよらに 特徵づけているのかに着目する。この視点をふま 克, 沖縄県の離島において産業的発展を遂げつつ あるモズク養殖の生産労働をささえてきた条件を 検討したい。この検討をとおして，沖縄県離島の 地域的特徵の一端, 寸なわら施政権返還後, 周辺 地域である沖縄県に対して講じられてきたわが国 の施策および米軍占領時代から，施政権返還を経
て今日まで沖縄県が执かれてきた特殊な政治的状 況が, 沖縄県内に点在する離島地域の生産活動の

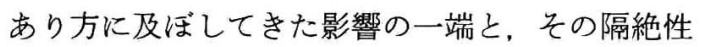
の高さゆえにこうした地域が有する社会構造の特 徵を明らかにすることを本研究の目的とする。

\section{2. 研究の方法}

本研究ではまず, 沖縄県離島地域における農業 㧍よびモズク屓殖それぞれについて，その生産労 働の実態の把握を試みる。このため責殖モズク生 産現場の実際，とくにモズク生産にかかわっての 各段階に打作業について調査し, 養殖モズク 生産労働の特徵を明らかにする。また，農業に関 して, 牛産労働の季節的配分の特徵を分析する。 
つぎに、これらを兼業するらえでの労働力配分に 関する問題点を述べたい。

ここで明らかになった問題点の解決において有 効な地域の条件のらち，まず政策的な施策にもと づくものをあげたい。さらに，生産労働を支える 地域社会の特徵について明らかにする。これら は，歴史的な推移のなかで論じていきたい。

最後にこれら地域的条件のらち，とくに社会的 条件に着目し，その由来について検討し，本稿の 研究目的を達したい。

\section{3. 研究対象地域}

本研究の事例地域として, 沖縄県内に拈いても とくに隔絶性が高い離島地域である伊平屋村 3 ) を選定した 4 )(第 1 図)。伊平屋村に拈いては，第 二次世界大戦前からサトウキビおよび水稲生産を 中心とした農業がもっばら営まれてきたが，この 兼業経営として，1980年代初頭からモズク養殖が 導入された。琉球列島の中で伊平屋村の主島であ る伊平屋島は, 地形的には山地島に分類され 5 ), 山地に挴いて涵養される水資源が豊かである。こ れを農業用水にもちいた水稲生産は伊平屋村を特 色づけているが，水稲生産にかかわる作業をと打 して住民のなかに培われたこまやかな管理作業の リテラシーがモズク養殖に生かされ，網の掃除や 雑草の除去などがこまめに行われ，これにより高 品質のモズクが産出されている。

この結果, 伊平屋村に执いては養殖モズクの産 地形成が進んだ。伊平屋村のモズクの生産量をみ ると, 1995年から1999年の平均で692トンであり, これは沖縄県の市町村のなかでは第 4 位に位置し て括り, 離島地域では平良市（宮古島）に次ぐも のとなっている。

\section{II. 対象地域の生産労働の特徵と労働力配 分に関する問題点}

\section{1.モズク養殖生産労働}

ここでは, 現在の養殖モズクの生産作業につい て，その実態の報告を行ら。

伊平屋島拄よび野甫島の周囲のサンゴ礁池に は, 注洼全域に「区画漁業権もずく特区」が認可 されて扣りこのなかに漁場が作られる。モズク
養殖網は，海底に垂直に打らこまれた鉄棒によっ て支えられる。養殖網は幅 $1.8 \mathrm{~m}$ ，長さ $20 \mathrm{~m}$ をた は2 $2 \mathrm{~m}$ のノリ網を用いる。鉄棒は $1.5 \mathrm{~m}$ に切りそ ろえられた建材用丸鋼が使用され、コンプレッ サーを用いた専用機械によってその全長の拈よそ 3 分の 1 から 4 分の 1 が海底に打ちこまれる。鉄 棒は数年間更新されずに海底に設置しておかれる ため, 各養殖業者はサンゴ礁池の中に多数確保し ている自分の現場を、設置されている鉄棒によっ て識別できる。現場の占有についてのきまりはと くになく，居住している地区による制約もない。 区画漁業権が設定されている海域において，モズ ク養殖業者は各々自分が鉄棒を打った場所を占有 することができる。伊平屋村のモズク養殖業者た ちは，区画漁業権漁場の中で，慎重に場所を選択 しながら年間を通じて新たな漁場作りを行ってい る。

以下に，伊平屋村に括けるモズク養殖の生産労 働について，年間作業暦（第 2 図）をもとに述べ る。モズク養殖は, 種培養と採苗, 沖出し, 収 檴, 荷揚げと運搬, 加工と出荷という手順で行わ れる。

モズクの種は, 寒天を満たしたシャーレのなか に植えこまれ，一定温度に保たれた室内において 眠ったまま越夏される。この種の培養は, 秋から 冬にかけて行われる。第 2 図の事例盖殖業者は, 10月上旬から種培養を開始している。従来, 種培 養は水槽を用いて行われたが，現在はフラスコを 用いる方法が主流になっている。伊平屋村では旧 暦の10月15日から採苗が始められ，その後は扣よ そ15日サイクルで採苗が行なわれる。水槽に 7 日 間から10日間汪ど網を浸し，機械による酸素供給 を行いながら盤状体を養殖用の網に採苗する。

伊平屋村内の海岸沿いには, なかにコンクリー 卜製の水槽が設置されている採苗施設が点在して いる。これらは「モズク小屋」と呼ばれており, いくつかの経営体は, こうした施設を利用してい る。モズク小屋に扮いては，ポンプにより汲み上 げた海水を利用して, 種培養扣よび採苗が行われ ている。また, 自宅敷地内に種培養および採苗の ための小型簡易倉庫を設け, ルームクーラーによ る温度調節をしながら種培養を行っているモズク 


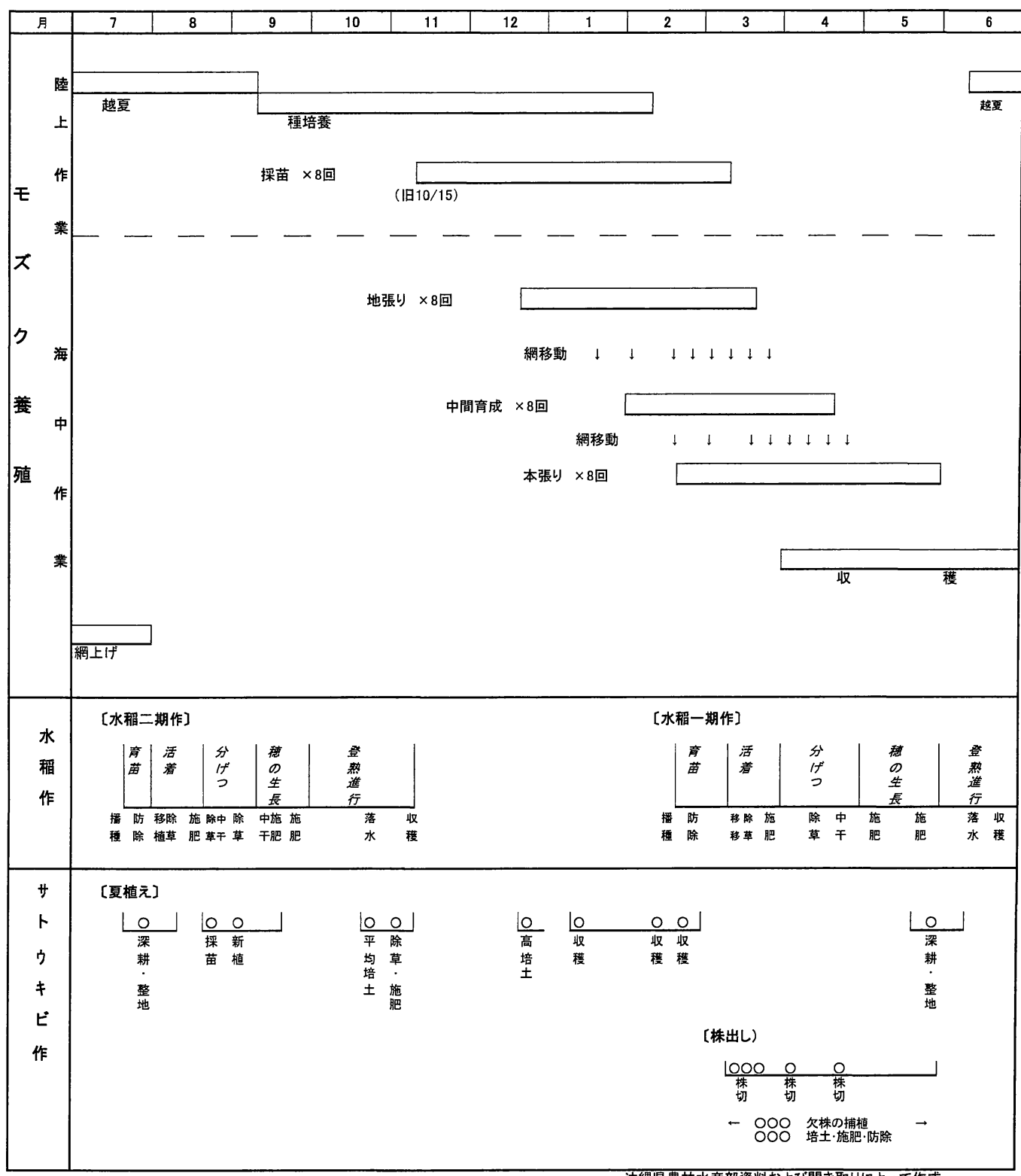

※ モスク養殖の $\square$ は作業を行う期間を示す。

沖縄県農林水産部資料およひ聞き取りによって作成

水稲作の しلおぬひ斜字は生育段階を示す。

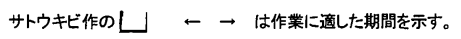

サトウキビ作の○は個で1日程度の作業量を示す。

第 2 図 沖縄県伊平屋村におけるモズク養殖、水稲作，サトウキビ作の作業暦

養殖業者もある。

1997年には伊平屋村漁港敷地内にエアコンディ ショナー装備の培養室や海水の殺菌装置, コンク リート製の採苗水槽16基などを備えた伊平屋村漁 業協同組合育苗生産施設が建設された。現在, 第
2 図の事例養殖業者をはじめとした 8 経営体が利 用料金を支払ってこの施設で種培養と採苗を行っ ている。

12月下旬からは, 網を海中に張り出す沖出し作 業が始まる。沖出しされた網は，藻体の成長にあ 
わせて移動されるが，その段階はお拉まかに地張 り，中間育成，本張りに分けられる。それぞれの 段階に適した底質, 水深, 水質があり, 各養殖業 者は試行を繰り返しつつ経験と勘によって網を張 る位置を決める。

沖出しは15日間隔で行われ, 一般には 1 シーズ ンに 4, 5 回の沖出しを行う。第 2 図の事例養殖 業者は 1 回目の沖出しを12月下旬に行ない，3 月 下旬まで 8 回の沖出しを行なっている。最初は海 底からわずかに離して網が張り出される。この段 階は発芽を目的としており，地張りと呼ばれてい る。地張りは網を 5 枚重ねたままで, 干潮時に露 出しない程度の水深の浅瀬に張り出す。モズクの 発芽には天然モズクが本来生育するような場所, すなわら様々なサンゴや多様な海藻類が繁茂して いる海域が選択される。その後藻体がわずかに伸 びているのが肉眼で確認できる程度になったら，

やや水深のある中間育成現場に網を移動させ, 海 底に近く網を張る6)。発芽から間もなくの藻体は 光合成をさかんに行らため, 底質としては日光の 反射が強い白砂が適している。第 2 図の事例養殖 業者は、1 回目に地張りした網を、ひと月あまり 招いた 2 月初旬に中間育成現場に移動させてい る。この後春先にかけては, 徐々に海水温が上昇 していき, 藻体の成長が早くなるため, 後に沖出 しした網ほど地張りから中間育成への移行に要す る日数が短くなる。

中間育成現場で藻体が数センチまで生育する と, 本張り現場へ網を移動させる。中間育成現場 でそのまま本張りを行う場合もある。沖出しから 本張りまでおよそ40日〜 50 日余りを要する。

本張り現場への移動後は, 藻体を本張り現場の 水質に慣れさせるため, 網は広げずに 5 枚重ねの ままで張られる。1日あたり括よそ100枚が張り だされる。およそ2週間後に網は広げられる。本 張り後は, 収穫まで除草が繰り返される。1 回目 の沖出しから, 最後の網の収穫まで様々な発育段 階にある網の管理を，養殖業者たちは行わなけれ ばならない。モズク㽰殖技術には未知な点もあ り，前年までよく育った場所で次の年はまったく 育たないといらことも多い。また, 自然条件の変 化によって1日で藻体が消えることもある。さら
に気象状況によっては，波浪により收穫を目前に した藻体が切れ，失われてしまうこともある。 1999年は平年並みの作況であったが，モズクの収 穫がまったくない経営体もあった。モズク養殖に 扣いては，一般に網入れした枚数に対して収穫で きる枚数は，良くて半分，普通で三分の一といわ れている。伊平屋村に拈いては，最大で执よそ 1,000枚の網を入れる養殖業者があるが，この場 合には持よそ400枚の收穫を見込んでいる。サン ゴ礁池のどこに網を張るか，そしてどらいったタ イミングでどこに網を移動させていくかがその年 の収穫を左右する大きな要因であるといえる。養 殖業者は絶えず気象や海況に注意しつつ，現場に 扣ける日常の管理作業を行いながら藻体の発育状 況を見守り, 必要に応じ何度となく網を移動させ る。こらした管理作業は冬季の低水温のなかで海 中に潜水して、コンプレッサーなどの簡易な機械 を用いた手作業によって行われている。

次に具体的な網の張り出しと移動の事例をみて みる。第 3 図の事例養殖業者U氏は前泊地区在住 のモズク養殖専業者である。3人の仲間とグルー プでモズク養殖を経営して和り，1998-1999年に は合計2,000枚の網を張った。地張りはAの海域 で行った。中間育成は深度が浅く，白砂の底質で あるBの海域を利用している。中間育成を経た網 は順次 C，D敃よび Eに移動され本張りされた。 この場合さまざまな場所に網を張ることによっ て、リスクの分散がはかられている。

4 月から 6 月にかけては收穫期となる。4 月に は, 中間育成, 本張り, そして養殖施設の設営と 平行して，早期に入れた網の収穫作業が始まるた め, もっとも繁忙な時期となる。収穫は, 通常 2 〜 人一組で行なわれる。

朝 8 時頃に出港し, 収穫作業は拉よそ 3 時間に わたって行われる。養殖業者本人が潜水して刈取 り作業を抏こない, 手伝いの者が船上で雑草等の 除去作業を行ら。刈り手は, ウエットスーツと酸 素ボンべを用いて潜水する。バキュームホースを 使って網からモズクを吸い取っていく。このとき 海底の砂や網のささくれを吸い込む可能性がある ため, 刈取りは慎重に行なわれる。船上にはモズ クを含んだ海水が吸い上げられる。船側にネット 


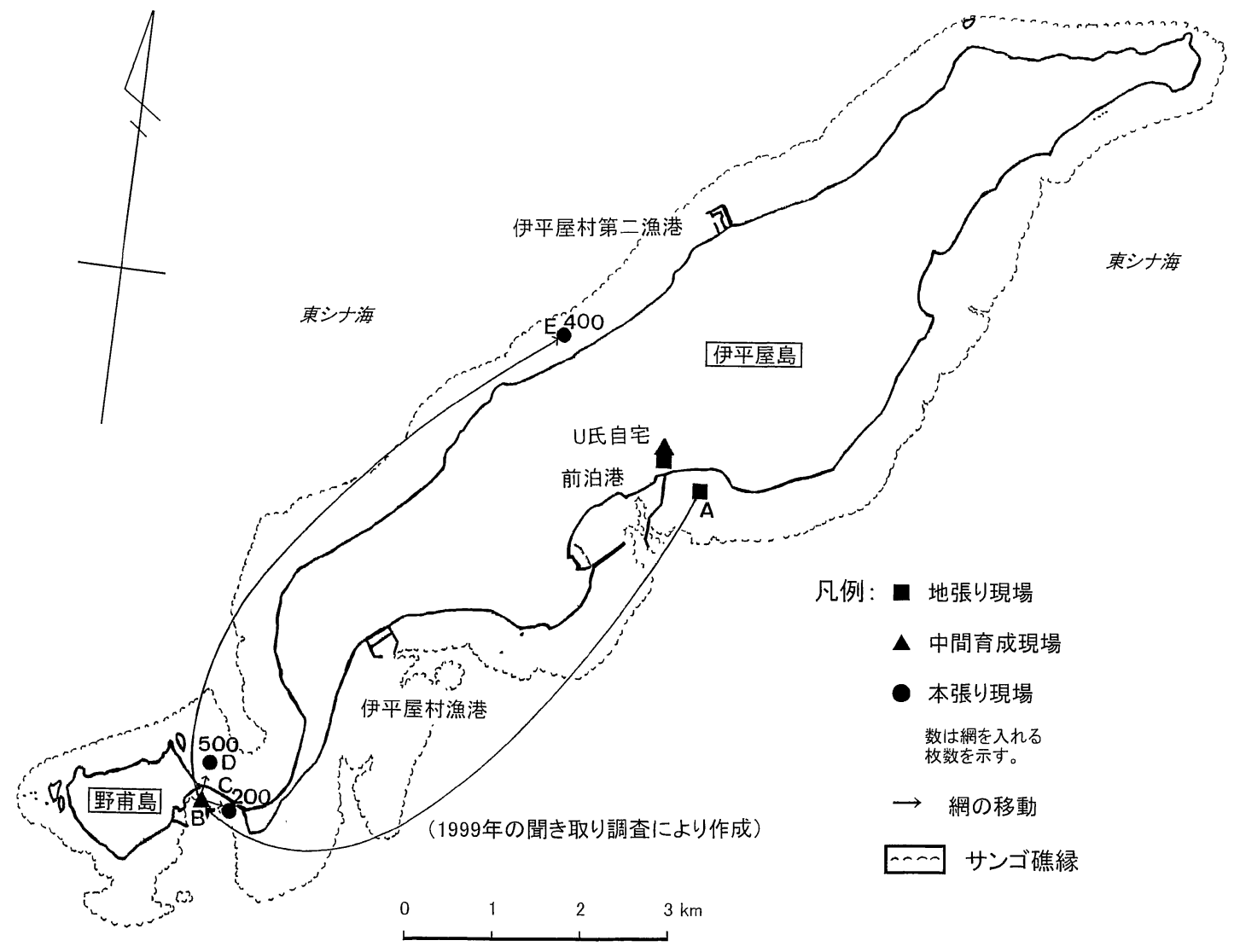

第 3 図 沖䋲県伊平屋村におけるモズク養殖網移動例

1999年の聞き取りによる

が設置されていて海水はそこで濾され，モズクが ネットの上に残る。刚取り作業者, 船上での除草 作業者のいずれも, 砂, 雑草, 網のささくれなど の混入が最小限となるように慎重に作業を行う。 熟練者は 3 時間で扣よそ20枚を収穫する。網はそ のまま張り出して拈けば再び藻体が伸び, もら一 度収穫ができる。異物があらかた取り除かれたモ ズクは, プラスチック製のトロ箱に収められ, 荷 揚げ場に運ばれる。

正午頃までに収穫は終了し, 村内各地区の荷揚 げ施設に船が着けられる。第 3 図の事例U氏は,

C, Dの現場で収穫したモズクを前泊港の岸壁 で，Eで収檴したモズクを伊平屋村第二漁港でそ れぞれ荷揚げする。

伊平屋村漁港に扣いては，着岸した船からホイ ストクレーン7）を用いて 6 箱ずつトロ箱が吊り
上げられ，個人所有の小型トラックに積み込まれ ていく。また, 伊平屋村第二漁港や各船揚げ場, 岸壁に拈いては, 小型クレーン搭載トラックを用 いて荷揚げ，積込みが行なわれる。 モズクは収穫された当日のらちに塩蔵加工する 必要があり, 養殖業者は積み込みが済むと, 自ら トラックを運転し前泊港構内の伊平屋村漁業協同 組合モズク加工場まで搬入する。加工場では午後 1 時から作業が始められる。搬入トラックが多い 日は, 昼休み中, 加工場横の駐車場に多くのト ラックが並んで順番待ちをする。養殖業者は搬入 を済ませると，除草などの作業のために午後から また海に出る場合もある。また，サトウキビ作や 水稲作との兼業を行なっている者は, 農作業に出 ていく場合もある。

モズク加工場は, 積出港である前泊港近くの伊 
平屋村漁業協同組合事務所の敷地内に設けられて いる。加工場は，荷受け，洗浄，塩蔵，缶詰めな どの加工施設と，倉庫とに分かれている。荷受け 場には養殖業者がトラックを直接つけることがで きる。そこで1名の作業員によって計量作業が行 なわれ，モズクは洗浄ラインに流される。水槽の 中での泡洗浄と 4 名の作業員による手作業での異 物除去によって洗浄が行なわれる。この洗浄の工 程は，モズク加工で最も重要な部分であり，この 工程がモズクの品質の評価に与える影響は大き い。洗浄後さらに 1 名の作業員によって異物の最 終検查が行なわれる。

洗浄が済んだモズクは，1名の作業員によって 大型の回転ドラムで塩と混ぜられた後に, 数日間 寝かされて藻体の水分が出される。その後ビニー ル袋で内装されてから18キロ缶に詰められる。18 キロ缶の内容は, $16 \mathrm{~kg}$ の原藻と $2 \mathrm{~kg}$ の塩といら 割合となっている。缶はいったん倉庫に積まれ, 順次伊平屋村営フェリーによって前泊港から沖縄 本島に出荷される。

以上から，モズク養殖の生産労働の特徵をあげ ると以下のようになる。第一に, 潜水装備の導入 や各作業に打ける機械化は進められているもの の, 陸上での農作業と比較して，機械化および省 力化には限界があり，モズク養殖の生産労働は手 作業に頼る部分が多い。第二に，モズク養殖の生 産労働は, 季節的な偏りが大さい。すなわち12月 下旬から 6 月下旬までの期間は，さまざまな発育 段階にある網の移動, 収穫, 網上げなどの作業 が，間断なく行われる繁忙期であり，とくに多く の労働力投下を必要とする。第三に, 網の除草な ど, 日々の管理作業は個人で行えるが, 網の沖出 し, 網の移動や収穫作業, 網上げあるいは養殖漁 場の設営などは共同作業により行われるため, 集 中的な労働力の調達が必要となる。

\section{2. 農業生産労働}

ここでは，モズク湌殖に組み合わされている農 業にかかわる生産労㗢の特徵について検討したい (第 2 図)。

サトウキビの収穫が行われる $1 \sim 2$ 月は, 前述 のように最も多くの労働力を必要とする時期とな
るといわれてきた。また 3 月中旬から 5 月下旬に かけては，株出し栽培のための作業に多くの手間 を必要とする8)。やはり 3 月には，水稲一期作に おける田植えが行われる。この時期は，モズク着 殖の繁忙期でもあり，農業とモズク養殖の双方に 扣いて，効率的な作業を行らためには，多数の人 手の調達の可否が問題となると考えられる。以下 に, この問題に対する対応について述べる。

\section{III. 労働力配分を可能にした政策に関する 条件}

伊平屋村は，わが国の中でも軍事施設がとくに 集中している自治体である沖縄県のなかに特かれ ている地域である。また，過柾地域としての指定 を受けている地域でもある。このため政策によ り，国执よび沖縄県から，さまざまな行財政上の 特別措置が実施されて怙り，これをもとに以下の ようなとりくみが進められた9)。

\section{1. 農業における機械化と省力化}

伊平屋村の農業における機械化は, 伊平屋村農 業協同組合による1962年のブルドーザー導入に始 まる（伊平屋村農業協同組合，1997）。こののち, 伊平屋村の農業生産に抢ける機械化は徐々に進め られたが，とくに1990年代に入ってからは急速な 機械化および省力化が進められてきた。

荒井（1998）は, 伊平屋村が離島地域であるが ゆえに，先鋭的に進められている農作業請負事業 の進渉状況に関する詳細な報告を行っている。

これによると伊平屋村農業協同組合は, 若者の 農業離れを防ぎ，兼業で成り立つ農業を実現する ために，「水稲とサトウキビの二大作物の機械化」 を推進してきた。このうち, 水稲生産は個別の農 家によってトラクターや田植え機などの機械が保 有される傾向がある。しかし, 防除や乾燥, 籾摺 りなどは，ほとんどの農家が伊平屋村農業協同組 合への委託作業に頼っている。一方, サトウキビ 生産に扣いては, 農業協同組合主導での大型機械 の導入による機械化が進められてきた。とくに, サトウキビ生産に沶いてもっとも多大な労働力を 必要とする収穫作業は，1991年から投入が進めら れたハーベスターを用いての，農業協同組合によ 
る委託作業が行われて扣り，完全に省力化されて いる。このため各農家は, 自己の労力をほとんど 使わずに収穫作業を終えることがでさるよらに なった。さらに耕起のためのパワーショベルや， サトウキビの梢頭部除去のための浮上選別機など も伊平屋村農業協同組合によって導入され，農家 からの委託作業が行われている。この結果, サ卜 ウキビを $10 \mathrm{a}$ 生産するのに必要な労働時間は, 沖 縄県の 139.9 時間に対し, 伊平屋村は 80 時間と なっている(1994年)。こうした機械化は，国抒 よび沖縄県からの高額な補助事業に依存して進め られてきた。この結果, 伊平屋村は, 農業に拈け る機械化, 省力化が, 沖縄県のなかでもとくに進 んだ地域へと変貌し，農業離れにブレーキがかか り，労働力の不足が補われている。

荒井（1998）はこうした省力化を, 過疎化，高 齢化の進む沖緡県離島の農業の維持のための条件 であるとしているが, 一方でこのような形態の農 業においては，収益率の低下が著しいことを指摘 している。そこで必然的に, 経営規模の拡大と複 合経営化，兼業化が試みられていることを報告し ている。

\section{2.モズク養殖における機械化とインフラストラ クチャ一整備}

前述のようにモズク養殖は, 農業の副業として 選択されてきた。モズク養殖に拈いても農業と同 様に, 省力化の推進が存立の重要な条件となる。

伊平屋村に打いて漁業協同組合が設立され，乇 ズク養殖が始められたのは1981年である。これに 先立って数年間，天然モズクの採集が行われてい たが,このころには, 素潜りでの作業が行われて いた。しかし，養殖が開始されるとまもなく伊平 屋村漁港内に酸素充填施設が造られ，この後徐々 に酸素ボンベを使っての収穫作業が普及した。 1980年代半ばには, 各漁船にコンプレッサーとバ キュームホースも導入された。現在では, ウエッ トスーツと酸素ボンベを用いての潜水作業が行わ れている。

またモズク養殖が始められた当時, 国による第 七次漁港整備計画の一環として伊平屋村漁港の建 設が進められて扣り，この事業は1988年に完成し
た。これ以後, 伊平屋村漁港はモズク養殖のため のインフラストラクチャーとして中心的な役割を 担ってきた。

また1988年からは, 伊平屋島の西海岸において 伊平屋村第二漁港の整備が始められた。もしも海 路で東海岸と西海岸の間を往来すると南北の岬を 回らねばならず，時間もかかり危険性も高い。こ のため伊平屋村漁港に船を熬留している漁業者 が，西海岸で操業する場合は船を簡易な台車に載 せてトラックで牽引し, 伊平屋村第二漁港へ陸送 する。この所要時間は，およそ20分ほどである。 このように伊平屋村第二漁港は，西海岸に拈ける モズク序殖の拠点として重要な働きをしている。

ところで西海岸は、サンゴ礁池の水深が浅す ぎ，そのままではモズク養殖に利用できない水域 が広がっていた。そこで1992年からは，サンゴ礁 池の浚渫工事による水深の確保, 漁場の拡大も行 われている。

また各地区にも，船揚げ場と岸壁が順次建設さ れ，これらの船揚げ場と二つの漁港も，陸路によ り短時間で結ばれ利用されている。あらたに整備 された二つの漁港および各地区の船揚げ場，岸壁 が陸路で結ばれ，積極的に活用されて，伊平屋 島, 野甫島の周囲すべてのサンゴ礁池内で効率の よい作業が可能となった。

漁港の建設と平行して，漁港の構内に拈いて は, モズク養殖に必要な各種の設備も順次整備さ れてきた(第 1 表)。現在, 伊平屋村漁港には, 船揚げ場，荷揚げ場，岸壁，ホイストクレーン, 伊平屋村漁業協同組合の製水施設，酸素充填施 設，伊平屋村漁業協同組合直営の給油所など，モ ズク養殖の省力化持よび効率化に関わる設備が注 ぼそろっている。

また, 機械化された伊平屋村漁業協同組合モズ ク加工場，最新の養殖技術を生かした伊平屋村漁 業協同組合育苗生産施設などの養殖業に関わる近 代的設備は，モズク養殖に括ける効率化と労働の 軽減をもたらした。とくに収穫されたモズクの洗 浄は，非常に手間を要する作業であるため, 漁業 協同組合の加工場の果たす役割は大きい（写真 1 )。

以上から，モズク養殖と農業との間での労働競 
第 1 表 沖縄県伊平屋村における漁港および漁 業関連施設の整備

\begin{tabular}{|c|l|}
\hline 年 & \multicolumn{1}{|c|}{ 整 備 内 容 } \\
\hline 1978 & 伊平屋村漁港建設開始（島尻地区） \\
1979 & 人力のモズク洗浄・塩蔵施設建設（我喜屋 \\
& 地区） \\
1980 & 冷凍製水所設置（漁港建設地内） \\
1981 & 酸素充填施設設置（漁港建設地内） \\
1983 & ホイストクレーン設置（漁港建設地内） \\
1984 & 船上げ場建設（前泊地区） \\
1988 & 伊平屋村漁協モズク加工場建設(前泊港内) \\
& 伊平屋村漁港完成 \\
1992 & 伊平屋村第二漁港建設開始（田名地区） \\
1997 & 大型モズク加工機導入（前泊港内） \\
育苗生産施設建設（伊平屋村漁港内）
\end{tabular}

伊平屋村漁業協同組合資料および聞き取りにより作成

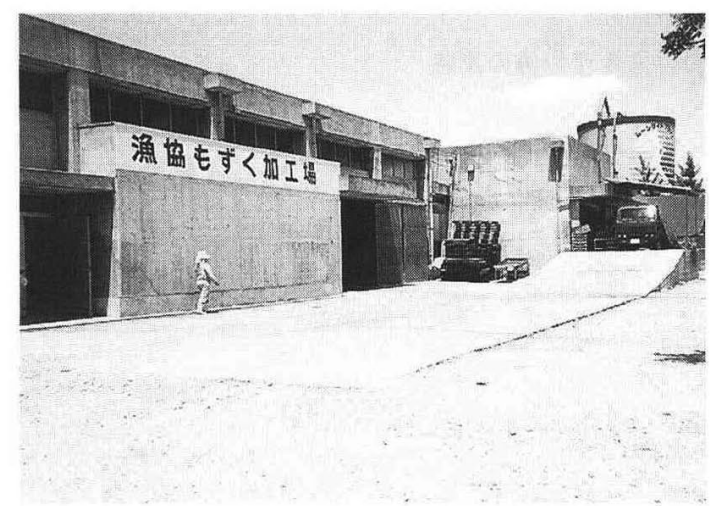

写真 1 伊平屋村漁業協同組合モズク加工場（1999 年 4 月)

合を避け，合理的な労衝力配分を行ららえで，農 業の省力化とモズク養殖に扣けるインフラストラ クチャーの整備が，重要な役割を果たしてきたと いうことができる。

\section{N. 労働力配分を可能にした社会構造に関 する条件}

上述したとりくみに加えて，地域に打ける限ら れた労働力の調整が，どのようなかたちで実現さ れてきたのかを以下に検討する。

\section{1. モズク養殖における共同作業形態の推移}

伊平屋村のモズク養殖に拀いては，機械化とイ ンフラストラクチャーの整備が進む以前には, グ ループによる共同作業が行われた。ここではま ず，このモズク養殖グループに着目し，その由来 と特徽を検討したい。

a ）地域の生産組織の歴史とモズク養殖グループ 伊平屋村に拀いては，モズク養殖の開始以前に も, 地域に拉ける生産組織が組織され活用されて きた（第 4 図）。

第二次世界大戦前から，1955年に機械による製 糖工場が操業されるまで、「砂糖与（サトゥク ミ)」とよばれるサトウキビ収檴および製糖のた めの組合が営まれた。また，1950年代後半から 1972年の施政権返還まで, 伊平屋村農業協同組合 の指導のもとにそれぞれの地区に組織されたタバ コ乾燥組合が存在した。これらの生産組織は, 原 則的に地縁を結合原理としつつも, 公的な組合と して存在していた。このため、これらの生産組織 のなかには，技術的な核となるリーダーの存在 や，バランスよく初心者，女性などを配置し、グ ルーブの中に包含する工夫などがみられた。生産 活動の場を陸上から海中に移したものの、モズク 養殖のためのグループもやはり、こうした互助協 働の性格をむつ組織の延長上にあった。モズク養 殖グループのできかたや活動の様子も、これらの 生産組織から受け継がれたものであった。

b ）モズク養殖グループの結成

伊平屋村では1970年代なかばから，天然モズク の採取がさかんに行われたが、このとさは地縁を もとにした任意のグループが組まれた。1981年か らモズク養殖が開始されるにあたり, 伊平屋村漁 業協同組合の指導によってモズク養殖のための生 産グループが, あらためて組織された。

初期のモズク養殖に打ける作業は、はとんどす べてが手作業であり，労衝力を多量に投下しての 大人数による共同作業が行なわれた。なかでも収 嚄時には, 養殖業者の協業に加光臨時雇いも動員 しての作業が行なわれた。

この様子を, 前泊地区における聞き取りにもと づいて以下に述べたい（第 5 図）。収檴には, 一 度に 3 隻の船が用られた。らち 1 隻は収穫の途中 で、すでに水掦げされているモズクを浜あるいは 


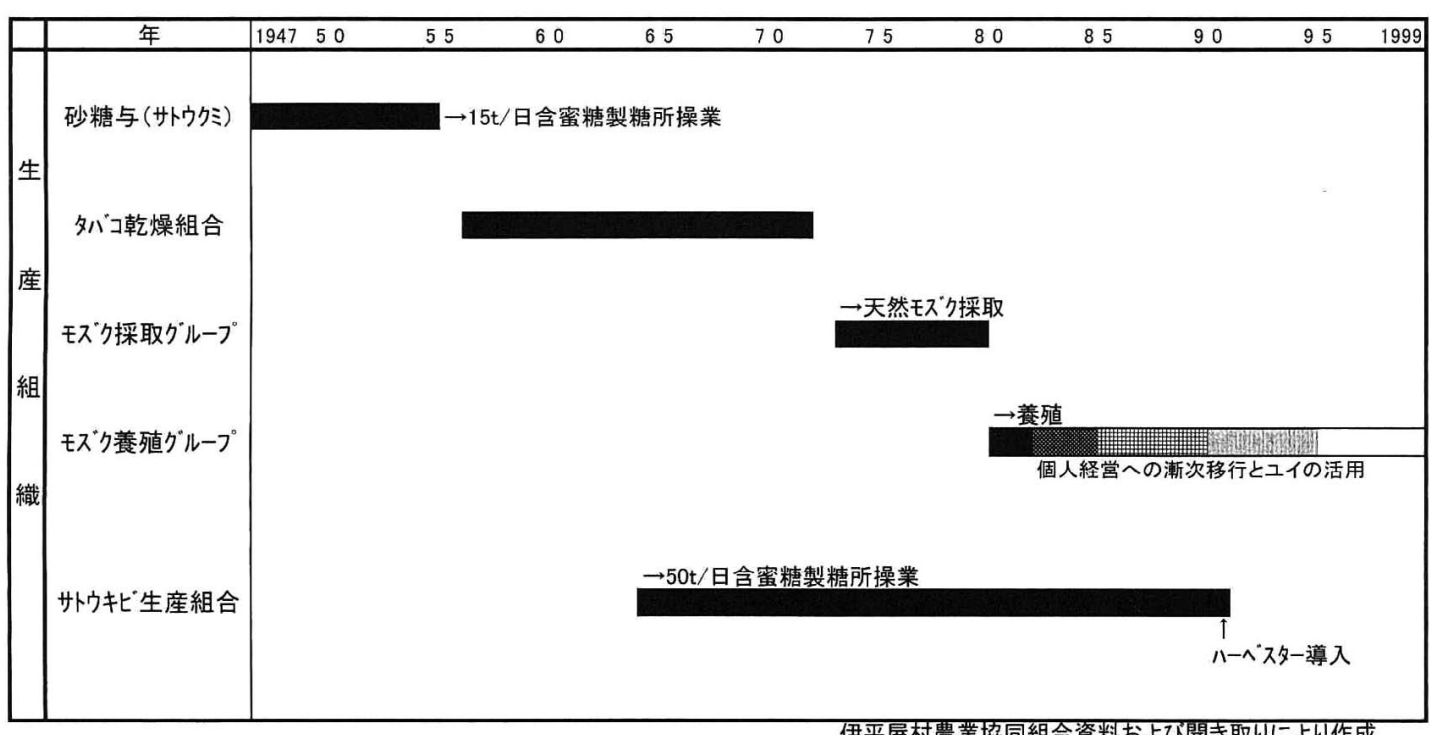

※図中のt/日は製糖所の1日あたりの生産能力を示す。

第 4 図 沖綶県伊平屋村における生産組織の推移

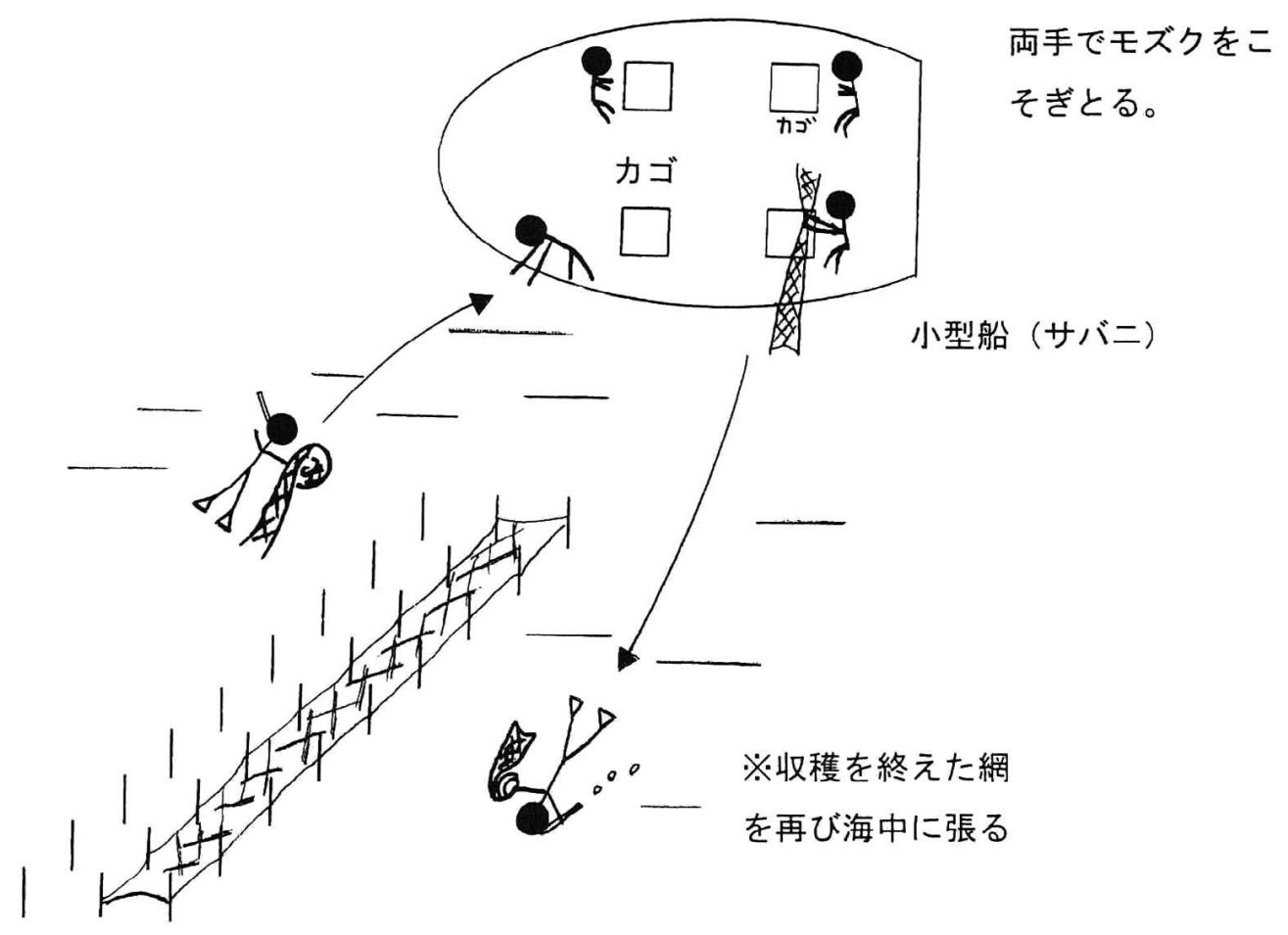

※船上の作業員は 両手でモズクをこ そぎとる。

第 5 図 沖縄県伊平屋村におけるモズク養殖導入期の収檴作業の様子

聞き取りにより作成 


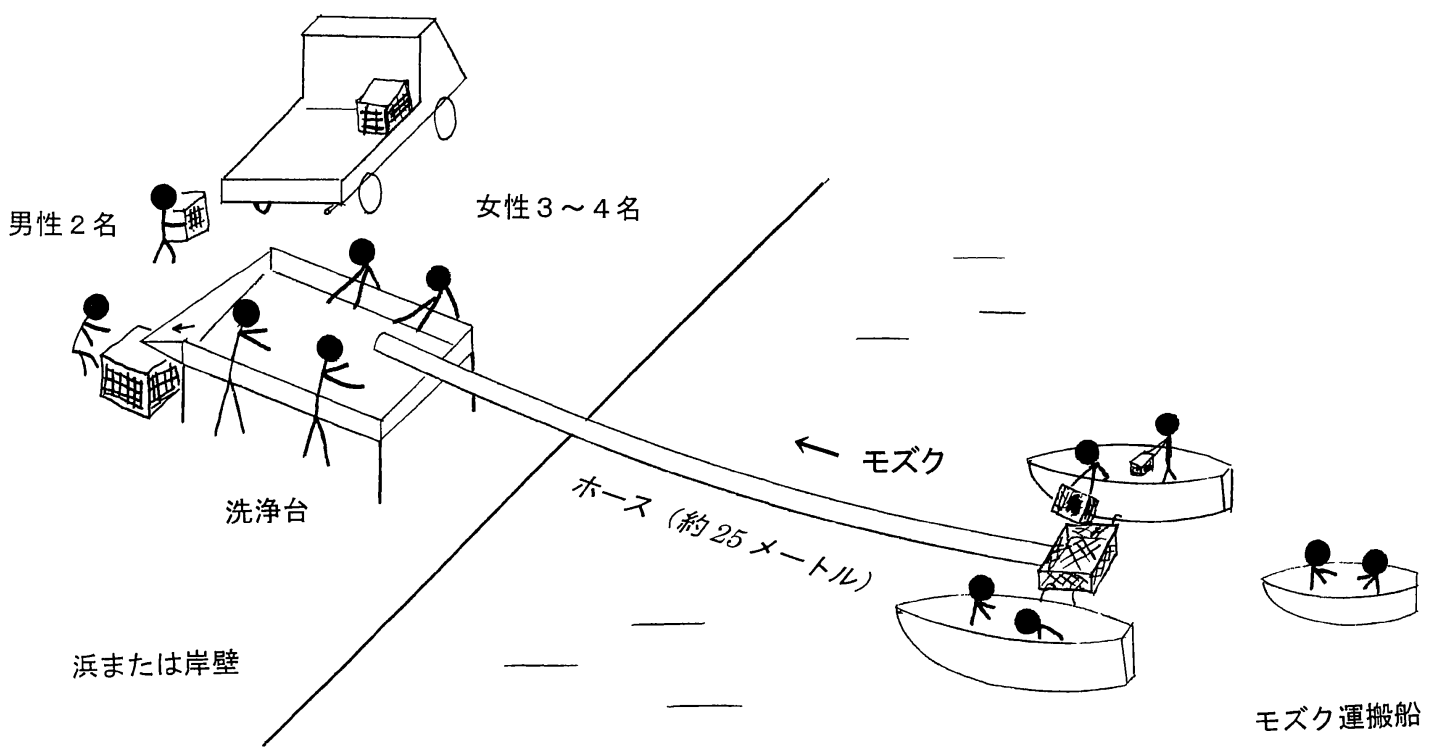

第 6 図 沖縄県伊平屋村におけるモズク養殖導入期の陸揚げと洗浄の様子

聞き取りにより作成

第 2 表 モズク養殖着業時（1981年）のグループ構成

一事例 : M 氏グループー

\begin{tabular}{|c|c|c|c|}
\hline 構 成 員 & $\begin{array}{ll}\text { 年 } & \text { 齢 } \\
\text { （当 } & \text { 時） }\end{array}$ & M氏（父）との関係 & 現在の生業 \\
\hline M氏（父） & 53 & 本人 & 農業 \\
\hline M氏（子） & 38 & 婿養子 & モズク養殖（個人）＋農業 \\
\hline F s 氏 & 49 & 近所 & モズク養殖（個人）十農業 \\
\hline I $r$ 氏 & 33 & 近所 & モズク養殖（個人）＋村議 \\
\hline F h 氏 & 54 & M氏（父）の友人 & モズク養殖（個人）十農業 \\
\hline N氏 & 不明 & 近所・親戚 & 死亡 \\
\hline
\end{tabular}

聞き取りにより作成

岸壁まで運搬するための船であった。潜水作業者 は, 半裸でシュノーヶル, 足ひれを用いて潜水 し，海中から藻のついた網を上げてきて船上に渡 す。船上には 4 名の作業者が乗っており，海中か ら上げられた網を受け取り，モズクを両手でこそ ぎ取ってカゴにためる。このあと潜水作業者は, モズクがそざ取られた網を受け取り，再び海中に 張り出した。収穫後の陸揚げ, 洗浄, 塩蔵場への 搬出までが，村内各地の岸壁や浜に招いてすべて 手作業で行なわれた（第 6 図）。海岸近くに停泊 している船から，25メートルほどのホースを使っ
て，刈り取られたモズクが次々と陸揚げされる。 台の上では，4名注どの作業員が異物の除去をし ながら洗浄していく。洗浄されたモズクは，次々 とトロ箱に入れられ, 男性の作業員 2 名によって 小型トラックに積まれる。このころ伊平屋村漁業 協同組合の塩蔵場としては, 人力に頼るごく簡易 なものが我喜屋地区にあったが，洗浄が満足でな い場合は，塩蔵場で受け付けられなかった。この ため洗浄作業は, 細やかな神経と根気を要するも のであった。こうした陸上の作業員には女性の パートタイムなどの臨時雇いを用いたが，船上で 
はやはり養殖業者の共同作業が行なわれていた。 モズク㽰殖グループは, 田名, 前泊, 我喜屋の 各地区ではそれぞれ 1 グループ，島尻地区では 6 グループが組織された。このらち島尻地区では, 原則として近隣関係に基づいてグルーブ分けが行 なわれた。ここでは，話し合いにもとづいて友人 関係や血縁も考慮された。第 2 表に示した事例の M氏グループには漁業経験のある者が多かったた め、Ir氏のよらな漁業経験のない者が意図的に入 れられた。このように，モズク屓殖グループは漁 業協同組合の指導により作られたため，ある程度 互助的性格を有する生産組織であった。それぞれ のモズク養殖グループには，技術的な核となる リーダーが存在した。

前述のよらに，モズク養殖が開始されたころに おいては，その生産労働はほとんど手作業によっ て行われており，労働集約性は現在以上に高かっ たと考觉られるが，大人数に上る互助協働を条件 に，伊平屋村に扣けるモズク養殖は成立し得たの である。

\section{2. 地域の生産労働のなかでのユイ}

a）モズク養殖におけるユイ

モズク養殖グループは，伊平屋村に抋いてモズ ク養殖が導入された翌年の1982年に生じた県内の モズク価格の暴落をきっかけとして構成が流動化 した。またこの後, 機械化, 省力化が進められた ため、モズク養殖の経営形態はグルーブ経営から 個人経営へと推移していった10)。

個人経営においても，モズク生産労働のそれぞ れの段階に扣いて効率の良い作業を行らために は，しばしば共同作業が必要となる。伊平屋村は 隔絶性が高く、過疎化, 高路化が進み，地域のア ルバイト労働力などに，あまり期待することがで きない11)。また単純な陸上作業とは異なり、海上 での作業にかかわる熟練の作業者を，女性や高齢 者のパートタイム労働から得ることはできない。 家族内の男子労働力の活用も若干みられるが，伊 平屋村では核家族化が進んでおり ク着殖業者は，家族内からの安定した人手の確保 が容易ではない。

このため，かつて全国の農村や漁村に执いて一

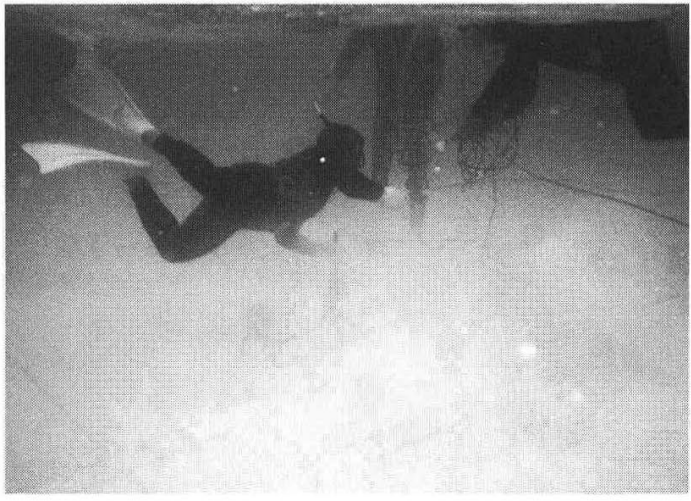

写真 2 モズク颓殖漁場作りにおける共同作業 (1999年 4 月)

般的にみられた「ユイ13)」が，労働力確保のため に活用されている。

写真 2 は，1999年 4 月中旬に行われた，中間育 成のための漁場設営の様子である。この日の作業 は，漁船 1 隻とコンプレッサーを用いたくい打ち 機を活用して行われたが，朝から夕刻まで，泀湆 1 日の作業を要した。ここでは，4名のモズク養 殖業者によるユイが行われ，夕刻には伊平屋村漁 港に㷌港した。これは，技術的に熟練した同業者 間での共同作業が，きわめて手際よく行われてい る事例である。

ユイは，モズク養殖の各段階においてみること ができるが，とくに繁忙となる収檴期においては 顕著にみられる。第 7 図は，モズクの加工を一元 的に担っている伊平屋村漁業協同組合モズク加工 場へのモズク原藻の搬入に関して，日ごとの搬入 経営体数を表している。この年のモズク養殖業者 は，35経営体であったが，収穫作業において2 3 人によるユイが行われているため，日々の搬入 経営体数は，1日を除いて総数の半分から三分の 一以下にとどまっている。モズク収穫に拈けるユ イは，作業前日の夕刻あるいは当日に，伊平屋村 漁港内の休䕀場所などで，モズク養殖業者間の雑 談のなかなどで組まれることが多い。こうしたユ イの枠組みは，地縁や血縁などにまったくとらわ れておらず，偶然その場に居合わせたものがパー トナーとなることが多い。モズク養殖に打ける工 イに叔ける労動の貸借は，近いららに，借りたむ のと等しい量の労働力を提供することによって相 


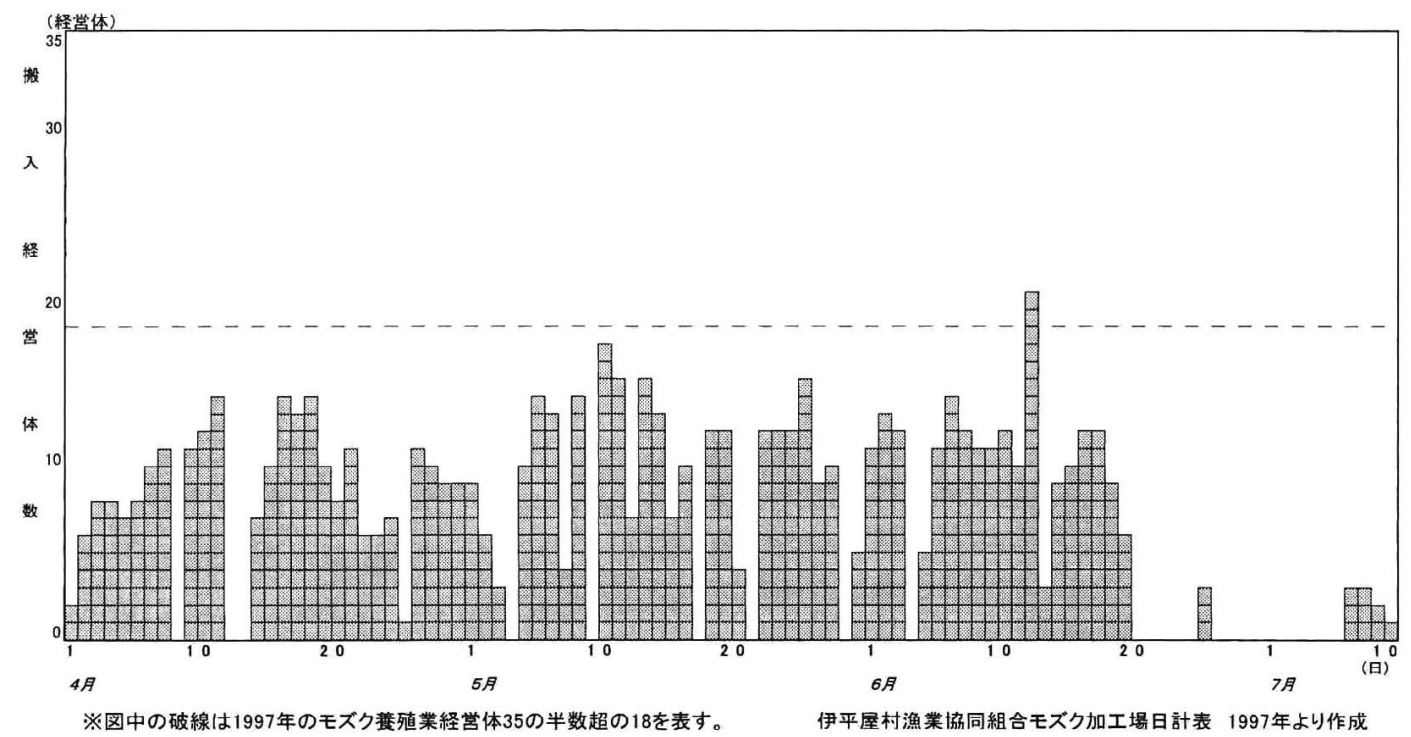

第 7 図 沖縄県伊平屋村漁業協同組合のモズク加工場における日別搬入経営体数（1997年）

殺される。

近年では，比較的大きな規模でのモズク養殖を 専業で行い, 農業は行わないものもみられるよう になった14)。彼らは，モズク養殖の繁忙期である 冬季には漁䈍活動をあまり行わない。これに対 し、モズク養殖の閑期である夏季には，扣もに個 人での潜水漁を中心とした活発な漁が行われてい る。

b ）農業に拈けるユイ

現在，モズク養殖と組み合わされる農業に関わ る生産労働のなかでも，しばしばユイが行われて いる。第 3 表は，サトウキビ生産を兼業するモズ ク養殖業者によって組まれたユイの事例である。 この事例は，モズク養殖の繁忙期である冬季に行 われたものではないが，サトウキビの夏植えとい う，酷暑のなかでの手作業に頼る，きわめてきつ い生産労働を乘り切るために組まれたものであ る。

この事例のユイは，血縁を中心に組をれている が，近隣の者どうしがユイを組む場合もある。労 働の貸借は，やはり等しい量の労働を返すことに よって清算されるが，青年，壮年の男性と女性や 高齢者との労働量の差異について撖密に清算する ことはない。またこらした清算は，それほど近々 に行われる必要もない。

この事例のモズク養殖業者は，モズク養殖にお。
第 3 表 沖縄県伊平屋村におけるサトウキビ夏 植えでのユイの事例（1999年 9 月）

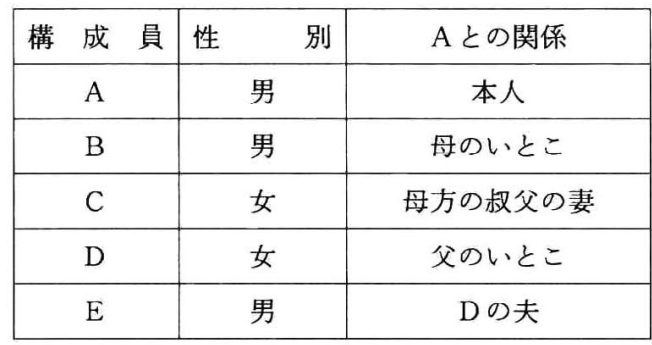

聞き取りにより作成

ける繁忙期に物いては，非常に手間がかかるとい われているサトウキビの株出し作業は省き，やは りモズク養殖の繁忙期と重なる水稲一期作の田植 えに打いて第 3 表と同様の枠組みでのユイを活用 し，この時期を乗り切っている。また前述のよう に, 伊平屋村においてはサトウキビの收檴は機械 化されているが，収穫期に荒天が続いて烟が奴か るみハーベスターが使えない場合などには，やは り同様のユイによって労働力が調達され，収檴作 業が行われる。

以上から，伊平屋村に扒いてはユイが有効に活 用されることにより農業生産が行われて和り、こ

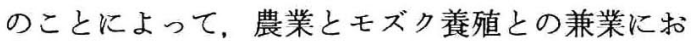
ける繁忙期の労働力調達が可能となっていると考 えることができる。 


\section{V．地域におけるユイの維持}

\section{1. サトウキビ生産組合の活動とユイの維持との 関係}

上述のように，伊平屋村に拈いては伝統的な互 助協働の枠組みであるユイが活用され，農業およ びモズク養殖に関わる生産が維持されてきた。し かし全国的にみると，かつてひろく行なわれてい た「労力交換」は近年あまり行なわれなくなって いる。第 8 図から，農作業での「手間替壳・ゆ い」を行った農家は, 全国, 沖縄県全体, 沖縄県 離島地域，伊平屋村それぞれに抏いてしだいに減 少したことがわかる15)。このなかで, 沖縄県離島 地域に执いて，なかでも伊平屋村に拈いては， 「手間替え・ゆい」を行った農家は相対的には高 率を示して扣り，農作業に和ける労力交換が, 他 の地域と比べて，さかんに行われてきたことがわ かる。

伊平屋村に执いては，家屋の増改築などの共同 作業や，住民間でのグループ金融など，生産労働 以外の社会生活なかのさまざまな場面において も，互助協働が行われている様子を観察すること ができる。また，住民からは「ユイ」あるいは 「ユイマール」といら言葉がしばしば聞かれるが, まさに伊平屋村の地域社会は, 互助協働に基づい た社会であるといっても過言ではない。こうした 社会構造が, 生産活動に批けるユイの基盤となっ て, 伊平屋村の農業やモズク養殖をささえている のである。

このように, 互助協働にもとづく社会構造が強 力に維持されてきた背景として, 前章に特いて述 べたさまざまな生産組織が営まれてさたことをあ げることができる。

これらの生産組織のなかでも，サトウキビ生産 組合の活動が果たした役割はとくに大きい。伊平 屋村では, サトウキビは含蜜糖として製糖されて いる16)。伊平屋村に扔いては，1965年に現在の日 産50トン規模の製糖所が稼働した。永田（1988） によると, 含蜜糖生産に扮いては, 大型の製糖工 場の稼働とともに, 収穫扣よび製糖工場への搬入 のためのユニットとしてサトウキビ収穫グループ の立ち上げが必要となる。伊平屋村に沶いても,

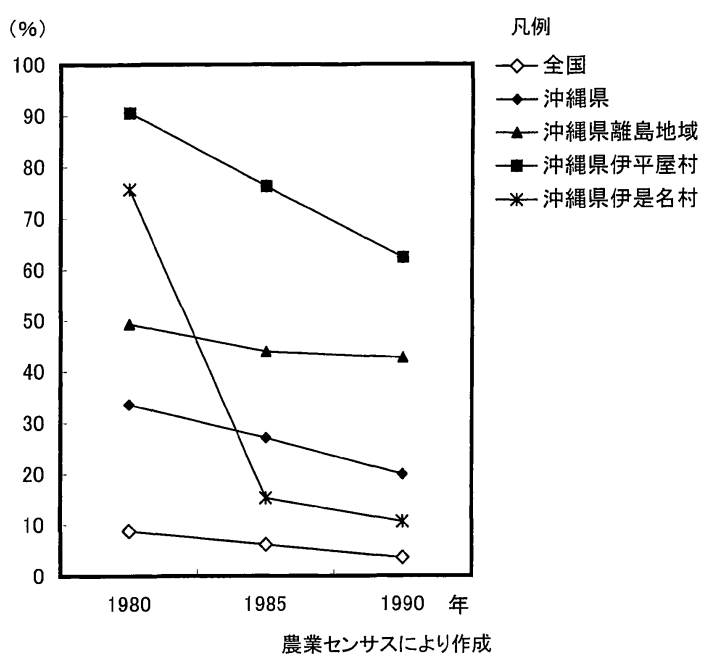

第 8 図 農作業においてゆい・手間替えを行った 農家の割合

サトウキビ収穫グループであるサトウキビ生産組 合が村内の各地区に打いて組織され，合計で12組 合が営まれた。さらに，それぞれのサトウキビ生 産組合には, 小組と呼ばれる下部組織が存在し た。小組は地縁, 血縁によるユイの枠組を踏襲し たものであった。小組は, サトウキビ春植えや田 植えなどの農作業を行う互助協働組織でもあった （比嘉, 1984）。1990年代にはいると, 前述のよう に伊平屋村農業協同組合の請負による収檴が主流 となった。これにともなって, 伊平屋村のサトウ キビ生産組合は消隇した。

サトウキビ生産組合は, 仲地・仲松 (2002) が 明らかにしているように, 賃金制をともなら組織 化された労力交換である。これに対して小組は, 賃金などによる厳密な清算をともなわず，伝統的 なユイの形態を維持した労力交換である。含蜜糖 生産のためのサトウキビ生産組合が1990年代初頭 まで組織され，その内部に小組が営まれたことに よって，沖縄県内に拈いて衰退がみられるユイの 慣習が，伊平屋村社会のなかに伝統的な形態のま まで維持され，農業执よびモズク養殖の作業に拈 いていかされていると考えることができる。

\section{2. 生産活動におけるユイ存続の地域的条件}

次に, 伊平屋村に执いてサトウキビ生産組合が 成立し，近年まで活動を行った背景について，地 域の農業が执かれている背景といら視点から考察 
する。

沖縄県に执いて現在すな招含蜜糖が生産されて いるのは, 伊平屋村を含めわずかに 7 つの離島地 域のみである17)。これらの地域に共通する特徵と して, 隔絶性が高く, 比較的耕地が狭小であるこ とをあげることができる。

このらち伊平屋村は, 主島である伊平屋島が比 較的大きな島ではあるにもかかわらず，山がちで あり, 耕地が狭小であるといら地形的特徵を持 つ18）。低平な台地が卓越する野甫島の耕地と合わ せても，伊平屋村のサトウキビ畑からは，1日50 トン程度の製糖原料しか生産できない。仮に水田 をすべてサトウキビに転作したとしても，やはり 分蜜糖の生産は不可能である19)。かつては，隣村 である伊是名村の製糖所へ船便で運び，分蜜糖に 製糖する試みがなされたこともある。しかし，海 が荒れた場合は原料の運搬ができず，また予想以 上に手間がかかったため，実験段階でこの試みは 断念された。沖縄県内の離島地域のなかには, 近 隣の島との架橋がなされたことによって，分蜜糖 への切り替えが可能となった地域もみられるが, 伊平屋村之伊是名村の間には相当な距離があり, その可能性は皆無である。

このため伊平屋村に拈いては，政府による買い 上げが保証されている分蜜糖生産への移行は見送 られ，含蜜糖生産が続けられてきた。伊平屋村の 隔絶性は, その狭小さとともに, 分蜜糖への切り 替えを妨げる要因であった。

ところで伊是名村は, 伊平屋村と同様にサトウ キビと水稲の生産がさかんな地域である。第 8 図 にみられるように, 伊是名村に沶いても1980年代 に入ったころは，農作業に打ける「手間替光・ゆ い」がさかんに行われていた。しかし，伊平屋村 に比べて平地に恵まれた伊是名村に扣いては, 1981年から300トン以上のサトウキビ原料確保が 可能となり，製糖の種別が含蜜糖から分蜜糖に転 換された ${ }^{20)}$ 。含蜜糖の収穫は, 生産組合を活用し て短期集中的行に行われることが求められるが, 分蜜糖生産に括いては，農家ごとのペースでの収 檴および製糖工場への搬入が可能である（比嘉, 1984）。したがって分蜜糖への転換以降，伊是名 村に括いてはサトウキビ収穫に括ける多人数での
共同作業は必要ではなくなり，これ以降農作業に 拈ける「手間替え・ゆい」がいちじるしく衰退し たと考えられる。現在，伊是名村に拈いては，モ ズク養殖にかかわってのユイもほとんど行われて いない21)。

以上から，沖縄県の離島地域のなかでもとくに 隔絶性が高く耕地が狭小な伊平屋村で続けられて いる含蜜糖生産と, この地域に执いてモズク養殖 を支えているユイの存続と活用との間には相関関 係が存在していると考光ることができる。

\section{И. おわりに}

沖縄県の離島地域である伊平屋村においては, サトウキビ拈よび水稲の生産を行ら農業の副業と して，1981年からモズク養殖が導入された。 モズク湌殖では，網の移動や管理などがしばし ば必要となるが，これらは潜水によって行われて 扣り，モズク生産に関わる作業はきわめて労働集 約性が高い。またモズク養殖にかかわる作業の中 には，共同作業で行われ，集中的に多くの人手を 必要とするものがあり，隔絶性の高い離島である この地域においては, 労働力の不足が問題とな る。

この問題は, 離島地域, 過疎地域を対象とした 行財政的な補助を活用し，農業協同組合および漁 業協同組合が主体となって農業およびモズク養殖 に拈ける省力化を推進してきたことによって緩和 されている。

また，地域において維持されてきた互助協働の 慣習が活用されることにより, 必要な労働力が調 達され，効率的な生産活動が実現されてきた。

伊平屋村に打いてモズク養殖が開始された当初 は，地縁にもとづく共同経営によるグループが組 織された。ほとんどの作業を手作業に頼っていた この時期においては, このグループはモズク生産 を支觉る条件であった。モズク養殖グループは， これ以前の伊平屋村に颃いて試みられたさまざま な生産活動のなかで存在してきた互助協働のため の生産組織の延長上にあると考えることができ る。

個人経営によるモズク養殖が一般的となった現 在では，農業とモズク養殖にかかわる生産労働の 


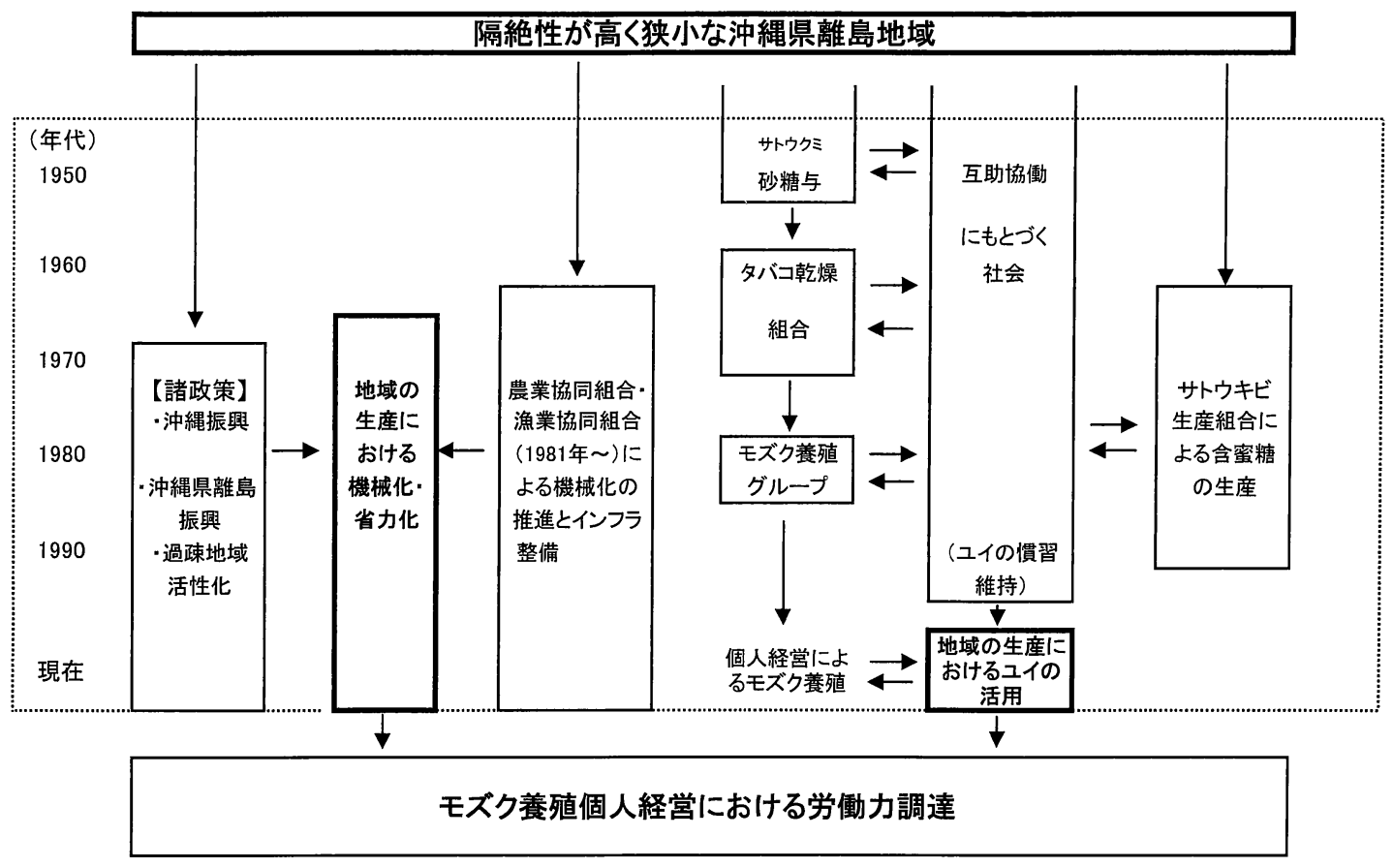

第 9 図沖縄県伊平屋村の養殖モズク生産を支える政策的・社会的背景

なかで, 伝統的な互助協働の慣習であるユイが活 用され，労働力の調達が可能となっている。また 伊平屋村に㧤いては，青年，壮年層を中心に，乇 ズク養殖専業者が存在するが，彼らもやはり一連 の作業の中で複数の人手を要する場合には, ユイ を行っている。

こうしたユイの慣習は，近年全国的に衰退がみ られたが，伊平屋村に䏡いては，比較的活発に営 まれてきた。この背景として，サトウキビ生産組 合が果たした役割はとくに大きい。サトウキビ生 産組合は，含蜜糖の生産地域に打いて組織され る，地縁をもとにした生産組織である。沖縄県の 離島地域のなかでも, とくに隔絶性が高く, 耕地 が狭小な地域に扣いては含蜜糖の生産を続けざる を得ない。このため伊平屋村に拈いては，サトウ キビ収穫が完全に機械化された1990年代初めま で, サトウキビ生産組合が活用された。このこと が, この地域の社会に和いて伝統的なユイの慣習 が維持されてきたことに, 深く関係していると考 えることができる。

以上から, 特殊な政治的状況にたつ沖縄県に立 地する離島地域であるがゆ兇投下された多額の
政策的資金と，これを活用しての農業協同組合お よび漁業協同組合による施策，加えて，地域に抏 ける生産活動の歴史的な推移のなかで維持されて きた互助協働にもとづく社会構造を背景として伊 平屋村に剅けるモズク養殖が存立していることが 明らかになった（第 9 図）。とくにモズク養殖に かかわる生産労働の維持の背景として, 互助協働 にもとづく社会を基盤に，その時々に拉いて生産 組織が営まれ，このことにより互助協働にもとづ く社会が維持されたことが示された。このこと は, 伊平屋村が, 沖縄県のなかでもとくに隔絶性 が高く狭小な地域であることに起因していると考 えることができる。

本研究では, 沖縄県内に分布している狭小な離 島地域が，基本的には農業地域としての性格を有 しつつ, 水産養殖業の産地形成に扣いて, 周辺海 域の豊かさに加えて，政策的な有利性およびこの 地域に特徵的な社会的条件を備兄ているという可 能性が示されたといらことができよう。

沖縄県では, 200カイリ制度の導入以降, それ まで重点が置かれてきた沖合や遠洋に拉けるカッ オ，マグロなどの回遊魚の漁獲に陰りがみられる 
よらになった。一方で, 沖縄県が長大な海岸線を 有していることから ${ }^{22)}$, 島嶼の周辺海域が漁業生 産の場として見直されてきた（沖縄県農林水産 部，1986)。沿岸域のなかでもサンゴ礁池は，水 深が浅く静穏であり, 水産養殖業の適地として温 帯に技ける内湾に匹敵する。このため水産養殖業 の展開は，沖縄県における産業振興のひとつの方 策として有力視されて拈り，近年ではモズク以外 の海藻類や, 魚類, 貝類などの養殖も試みられて いる。沖縄県離島地域に拈いては, 水産物流通体 制の確立, 漁業協同組合の基盤の強化, 漁港整備 などのハード面の整備が急速に進められており， 水産養殖に活用しうる地域的基盤の立ち遅れが克 服されつつある。これに加えて, 離島地域におけ る水産養殖業の展開のためには，農業生産に拈け る省力化の推進が, 重要な条件となっているとい らことができよう。加えて，こうした基盤を活用 しつつ, 地域の社会構造の特徵をいかした生産労 働が住民によって営まれることが, 沖縄県離島地 域に括ける水産養殖業展開のための地域的条件之 なっているのではないかと考えられる。このこと を検証するため, 今後より多くの事例についての 検討を行い, 地域の社会構造と生産労働のありか たとのかかわりについての考察を進めていきたい と筆者は考えている。

\section{注}

1) 沖縄県に批いて，扣もに養殖されているモズク は, 褐藻ナガマッモ科に属し, オキナワモズク, ホ ンモズク，フトモズクなどと呼ばれている。サンゴ 礁池内の暖かくて静穏な浅海によく繁茂する。奄美 諸島から八重山諸島にかけて分布する（当麻, 1982)。本稿においては，モズクとはオキナワモズ クをさすこととする。沖縄県産モズクは, 全国で消 費されるモズクのほぼ全量を占めている。

2 ) 聞き取りによると沖縄本島のモズク産地である恩 納村では, モズク着殖に执いてフリーアルバイター が雇用される場合が多い。

3 ) 沖縄国際大学南島文化研究所による試算 (1984 年）によると, 沖縄本島周辺離島地域のらち, 伊平 屋村は那覇市からの時間距離が最も大である。

4 ) 伊平屋村は, 伊平屋島とこれ架橋されている野 甫島からなり，人口1,611，世帯数574（2004年 3 月）である。村内は, 田名, 前泊, 我喜屋, 島尻
（伊平屋島）打よび野甫（野甫島）の各行政区にわ かれている。

5 ）目崎（1980）を参照。

6 ）筆者が作業に同行した現場の水深は, 地張り現場 で干潮時に $1 \mathrm{~m}$ ほど, 中間育成現場で $1.5 \mathrm{~m}$ ほど, 本張り現場で $4 \sim 5 \mathrm{~m}$ ほどであった。

7 ）モズクをはじめとした漁獲物を漁船から陸揚げす るために, 伊平屋村漁港の岸壁には小型クレーンが 設置されている。

8) サトゥキビは, 収穫後に株をふたたび伸ばして収 穫することが可能である。これを行うことにより， 単位面積あたりの收檴量を増すことができる。伊平 屋村に执いても，かつては株出しが行われてきた が, 近年は, 過疎化, 高齢化に対応してハーベス ターによる収嚄作業が導入されたため土壌が硬化 し，株出しの実績が上がらなくなっている。このた め現在, 伊平屋村で株出しを行っている農家は, き わめて少数となっている。

9 ) 沖䋥県離島地域に対する政策的資金投入の根拠々 なる法律をあげると，次のようになる。1971年から 沖縄振興開発特別措置法が，これに代かり2002年か らは沖縄振興特別措置法が施行されている。この法 律にもとづく沖縄振興特別措置法施行令により, 現 在は県内の53件の離島が指定されている。また, 沖 縄県離島振興計画が, 1976年から現在までに 4 次に わたって実施されてきた。この注か離島地域の市町 村の多くは, 過蹯地域活性化特別措置法 (1989年か ら), これに代わる過柾地域自立促進特別措置法 （2000年から）によって過疎地域として指定されて おり，伊平屋村もこれ該当する。

10）現在, 伊平屋村におけるモズク養殖グループは, わずか 1 つである(1999年)。

11）沖縄本島のモズク産地に拈いては, 共同作業のた めの労動力は, 一般にフリーアルバイターや臨時雇 いでの土木作業従事者など雇らことによってまかな われる場合が多い。沖縄県水産試験場普及セン ター, 城間氏談。

伊平屋村に掠いても，モズクの收穫期などに数ヶ 月滞在し, 作業補助のアルバイトを行ら村外出身の 若者が存在する。しかしこれはごく少数であり, 臨 時に必要な労働力を十分に満たす存在にはなりえて いない。

12）伊平屋村内でモズク養殖業者がもっとも多く居住 している島尻地区のモズク養殖業者17経営体につい て家族構成について調べたところ, 大家族は 2 世帯 のみであり，残りの15世帯は核家族であった。

13）沖縄県に拈いては，労力交換を「ユイ」「ユイ 
マール」「イーマール」などと表現することが多い。 以後本稿では, このらち「ユイ」といら表現を招も と用いる。

14）伊平屋村のモズク養殖業者のなかには, 従来型の 経営形態である農業との兼業を行わず，モズク養殖 と漁獲漁業とを組み合わせる専業の漁業者が存在す る。たとえば，1999年 9 月の伊平屋村島尻地区での 聞き取りによると，この地区のモズク養殖業者16名 のうち, 農業との兼業は 8 名, 漁業のみを行うもの が 8 名であった。

15）農業センサスの統計項目が，1995年より「手間替 え・ゆい・手伝い」に変わったため, 互助協同的な 意味合いの共同作業・労力交換に限ったこれ以降の 統計は不明である。

16）糖蜜分を含んだ砂糖であり，沖縄，奄美では，ほ とんどが黒糖として生産される。含蜜等の場合，政 策的に含蜜糖価格差補助金として国と県の負担に よって最低生産者価格が支持されているが，他の糖 類のように国による買い取りは行われていない。な お，糖価は1980年代初頭から現在まで，抑制傾向が 続いている。

17）現在，沖縄県において，サトウキビが含蜜糖とし て製糖されている地域は，伊平屋村，粟国村，多良 間村，与那国町抢よび小浜島，西表島，波照間島 (以上竹富町) である。

18）伊平屋村の主島である伊平屋村の面積は，20.59 kñである。括よそ160ある沖縄県の島嶼（0.01 kn以 上）のなかでは10番目の広さである。しかし伊平屋 島はその拉よそ70パーセントが山地，丘陵地，台地 に属して括り平地飞恵をれていない。第二次世界大 戦後は, 山の斜面に沶いても棚田や段畑が作られた が，のちに機械化が進むにつれこれらは耕作放棄地 となった。伊平屋島に沶いて現在耕作されている土

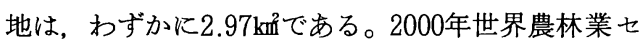
ンサスより。

19）伊平屋村農業協同組合関係者からの聞き取りによ ると， $300 \mathrm{t} /$ 日以上の製糖能力を有する製糖機械 を用いないとサトゥキビの搾り汁は赤ザラメになら ない。このため， $300 \mathrm{t}$ /日の原料確保が分蜜糖生 産の条件となる。

20）サトウキビ畑の面積は, 伊平屋村の78haに対し,

伊是名村は399haである (2002年)。沖縄県企画開発 部地域・離島振興局, 離島関係資料より。

21）沖䋲県伊是名村役場，安里氏談。

22）沖縄県の海岸線の総延長は $1,713 \mathrm{~km}$ であり，全国 のおよそ 4 パーセントにおよぶ。

\section{文 献}

荒井 聡（1998）：さとらきび作収穫作業における請 負事業の存立条件一沖緡県伊平屋村の事例分析一. 南九州大学園芸学部研究報告, 28（b ), pp.5771.

長谷川健二・常 清秀 (2002): 企業的カキ養殖業の 構造変動一広島県を対象として一. 地域漁業研究, 42 ( 2), pp. 43-65.

比嘉輝幸 (1984）：伊平屋村に打ける結（ユイ），沖縄 国際大学南島文化研究所:「伊平屋 - 伊是名調査報 告書」. pp. 15-24.

伊平屋村農業協同組合 (1997) : 「伊平屋村農業協同組 合50年史」．伊平屋村農業協同組合， $392 \mathrm{p}$.

来間泰男 (1979) : 「沖縄の農業」日本経済評論社, $238 \mathrm{p}$.

目崎茂和 (1980): 琉球列島に拈ける島の地形的分類 とその帯状分布. 琉球列島の地質学研究, 5, pp. 91-101.

森 畺一郎 (2003): 沖縄県離島に打ける養殖モズク 産地の形成一沖縄県伊平屋村を事例として一. 地域 漁業研究, 43 ( 3 ), pp. 23-43.

永田淳嗣（1988）: 多良間島に打けるサトウキビ生産 形態. 人文地理, 40, pp. 63-74.

仲地宗俊 (2001) : 戦前気沖縄の農村に括ける労働交 換慣行の構造. 村落社会研究 7 (2), pp. 13-24.

仲地宗俊・仲松辰弥 (2002): 沖縄県波照間島農業に 括ける貨金制ユイマールの現代的意義. 村落社会研 究 9 (1), pp. 35-47.

中村周作 (2003) : 延岡市島浦島の経済的地域構造.

平岡昭利編著「離島研究」. 海青社, pp. 183-200.

沖縄県農林水産部（1986）: 「沖縄県水産業の振興方

向」. 沖縄県農林水産部魚政課, $176 \mathrm{p}$.

大島襄二 $(1964)$ : 水産養殖業の地理学. 人文地理,

16 ( 1 ), pp. 64-72.

大島襄二 (1966)：壱岐真珠養殖業の地域的性格。漁 業経済研究, 14 (3), pp. 21-37.

当麻 武 (1982)：モズクの養殖一オキナワモズクに ついて一. 養殖, 6 (19), pp. 56-67.

上田不二夫 (1987)：系満漁民の発展。中楯興編著

「日本に打ける海洋民の総合研究 (上)」. 九州大学 出版会, pp. 55-76.

浦城晋一 (1993): 日本浅海養殖業の諸問題. 漁業経 済研究, $28(1 \cdot 2)$, pp. 36-59.

吉木武一 (1979): 離島漁業の展開条件について。西 日本漁業経済論集, 18, pp. 7-10. 


\title{
The Regional Bases for Mozuku Producing Labor in Iheya Village, Okinawa Prefecture
}

\author{
MORI, Shinichiro*
}

Key Words : Mozuku Producing, Labor Saving, Cooperation, Unrefined Sugar, Iheya Village

The purpose of this study is to consider the regional bases that have made it possible to keep producing mozuku, particularly the regional bases for mozuku producing labor. The study area is the Village of Iheya, Okinawa Prefecture.

The farmers in Iheya Village have kept producing mozuku as a sideline since 1981. As they have suffered from depopulation in Iheya Village, they need to ensure sufficient labor to maintain mozuku producing with farming.

They have made use of governmental funds for the distant islands of Okinawa Prefecture, then this problem is solved by labor saving on farming and mozuku producing. In addition, they cooperate in working. This Cooperation is called ' $y u$ ' e.g., the custom for working together in the region, so they can ensure sufficient labor for farming and mozuku producing. This cooperation is working efficiently.

We scarcely find the custom of 'yui' now in Japan, but we can still find it in Iheya Village. This is because there had been union activity for the unrefined sugar production industry. Iheya Village is especially far from Okinawa Island, and the land for cultivation in Iheya Village is limited. As a result they had been making unrefined sugar. That is why there had been union activity for unrefined sugar production until they started to use harvester machines at the beginning of the 1990s. Such factors resulted in maintaining the custom of ' $y u i$ ' in Iheya Village.

It can be summarized as follows; the inhabitants of Iheya Village can produce mozuku because they receive substantial governmental funds for the distant islands of Okinawa Prefecture, and because they have a custom of cooperation that we can find on small islands far from Okinawa Island.

\footnotetext{
* Mie Prefectural Ino High School, Mie University Graduate Student
} 